Article

\title{
GPR Survey on an Iron Mining Area after the Collapse of the Tailings Dam I at the Córrego do Feijão Mine in Brumadinho-MG, Brazil
}

\author{
Jorge Luís Porsani * (D), Felipe Augusto Nascimento de Jesus and Marcelo Cesar Stangari \\ Departamento de Geofísica, Instituto de Astronomia, Geofísica e Ciências Atmosféricas (IAG), Universidade de \\ São Paulo (USP), São Paulo 05508-090, Brazil; felipe.jesus@iag.usp.br (F.A.N.d.J.); \\ cesar.stangari@iag.usp.br (M.C.S.) \\ * Correspondence: jorge.porsani@iag.usp.br; Tel.: +55-11-3091-4734
}

Received: 10 March 2019; Accepted: 6 April 2019; Published: 10 April 2019

check for updates

\begin{abstract}
This article shows the interesting results of a pioneer effort by IAG/USP researchers to use ground-penetrating radar (GPR) for humanitarian purposes, guiding the rescue of victims in the tragedy of Brumadinho. The tailings Dam I at the Córrego do Feijão iron ore mine, located in the Brumadinho complex, Minas Gerais State, Brazil, collapsed on 25 January 2019. About 11.7 million $\mathrm{m}^{3}$ of mining mud was spilled from the dam, burying bodies, equipment, structural buildings, buses, and cars along a length of $8.5 \mathrm{~km}$ up to the Paraopeba River. Additionally, the contaminated mud traveled more than $300 \mathrm{~km}$ along the bed of the Paraopeba River toward the São Francisco River. This work shows the results of a geophysical investigation using the GPR method 17 days after the event. To carry out the geophysical survey, an excavator was used for soil compaction. The data acquisition was performed on the tracks left by the excavator chain using SIR-4000 equipment and antennas of 200 and $270 \mathrm{MHz}$ (GSSI). The GPR studies aimed to map bodies, structural buildings, and equipment buried in the mud. The location of the profiles followed preferably the edge of the slope due to the higher probability of finding buried bodies and objects. The GPR results allowed the detection of subsoil structures, such as concentrations of iron ore and accumulations of sand from the dam filter. The GPR was effective because the iron ore sludge in the mixing process became porous and the pores were filled with air, which provided penetration and reflection of the GPR electromagnetic waves up to a depth of $3.5 \mathrm{~m}$. The results were surprising. Although no bodies or underground equipment were found, the results of this research served to eliminate the studied areas from future excavations, thus redirecting the rescue teams and optimizing the search process. These important results can serve as an additional motivation for the use of GPR in future humanitarian work in areas of tragedies.
\end{abstract}

Keywords: GPR; tailings dam; Brumadinho; Minas Gerais State; Brazil

\section{Introduction}

Vale, one of the world's largest iron ore mining companies, owns the Córrego do Feijão mine complex. In 2018, this complex produced 8.5 million tons of iron ore, which is equivalent to $2 \%$ of the mining company's iron production [1]. Located in Brumadinho, about $65 \mathrm{~km}$ from Belo Horizonte city, Minas Gerais State, Brazil, the complex included dams, an administrative center with a dining hall and maintenance office, a cargo terminal, and a small railway network for the transport of iron ore (Figure 1). 

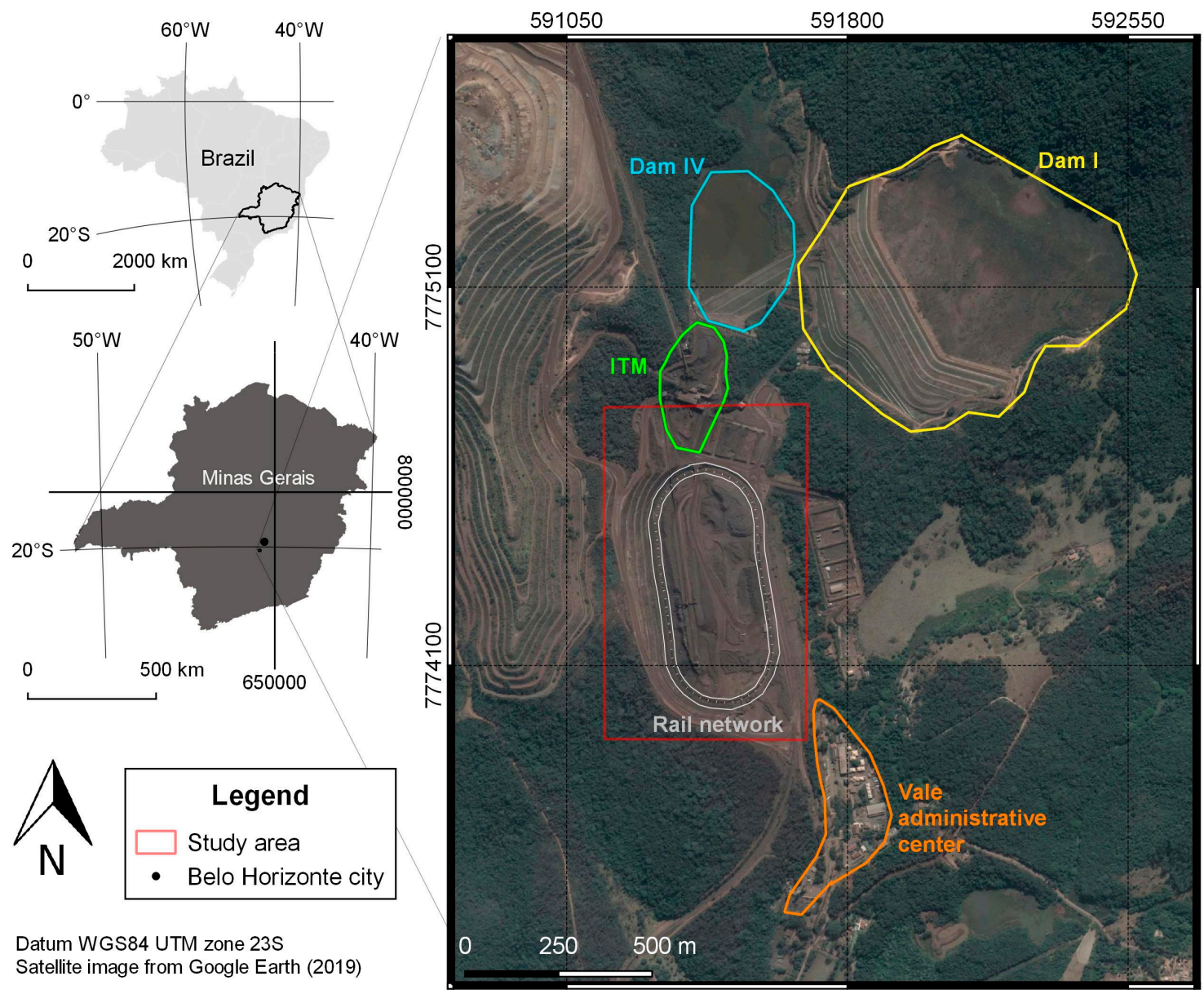

Datum WGS84 UTM zone 23S

Satellite image from Google Earth (2019)

Figure 1. Location of Córrego do Feijão mine complex, tailings Dam I, cargo terminal and small rail network, and Vale's administrative center.

The structure of the Córrego do Feijão mine complex was built on thick soil with high iron oxide content from the alteration of gneiss rock [2]. The mine is located on the slopes of the Quadrilatero Ferrífero and part of the Paraopeba River Valley. The Quadrilátero Ferrífero is an economically active area related to the extraction of iron ore, located on the southern border of the São Francisco Craton, characterized as an Archaean granite-greenstone terrain covered by volcano-sedimentary and Proterozoic sedimentary rocks [3].

Dam I was a megastructure of the Córrego do Feijão mine complex, measuring $720 \mathrm{~m}$ in length and $86 \mathrm{~m}$ in height. It was used for the disposal of iron ore tailings and sediment retention. Dam I was built by the Ferteco Mining company in 1976 using the upstream method and acquired by Vale in 2001 [1]. The tailings occupied an area of $249,500 \mathrm{~m}^{2}$ and had a volume of 11.7 million $\mathrm{m}^{3}$. The Institute of Water Management of Minas (Instituto Mineiro de Gestão das Águas-IGAM) and the National Mining Agency (Agência Nacional de Mineração—ANM) evaluated and classified Dam I as a structure with a high potential for pollution but a low risk for collapse. According to IGAM and ANM, Dam I was classified in the category of high damage potential, which means a high potential for significant losses of human lives as well as significant economic, social, and environmental impact. According to Vale, Dam I at the Córrego do Feijão mine stopped receiving iron ore tailings in 2015 and remained inactive since then [4]. In addition, the same dam received in 2018 declarations of stability that attested to its physical and hydraulic safety.

Regardless, the collapse of Dam I occurred on 25 January 2019, resulting in an event known as the "Brumadinho Dam I collapse". About 11.7 million $\mathrm{m}^{3}$ of a tailings-mud mixture was released from the dam, causing destruction along $8.5 \mathrm{~km}$ up to the Paraopeba River, extending for more than 
$300 \mathrm{~km}$ along the bed of the Paraopeba River toward the São Francisco River [5]. The event produced tailings-mud waves up to $30 \mathrm{~m}$ high, destroying the administrative center, dining hall, maintenance office, and railway network, which resulted in the burying of many bodies and equipment (machinery, vehicles, buses, etc.). Until 27 March 2019, 214 bodies had been found, and 91 bodies were still missing [6]. The causes of the Brumadinho Dam I collapse are still under investigation by Brazilian government agencies, such as the Federal Police and the Public Prosecutor's Office. Figure 2 shows satellite images obtained before and after the Brumadinho Dam I collapse.
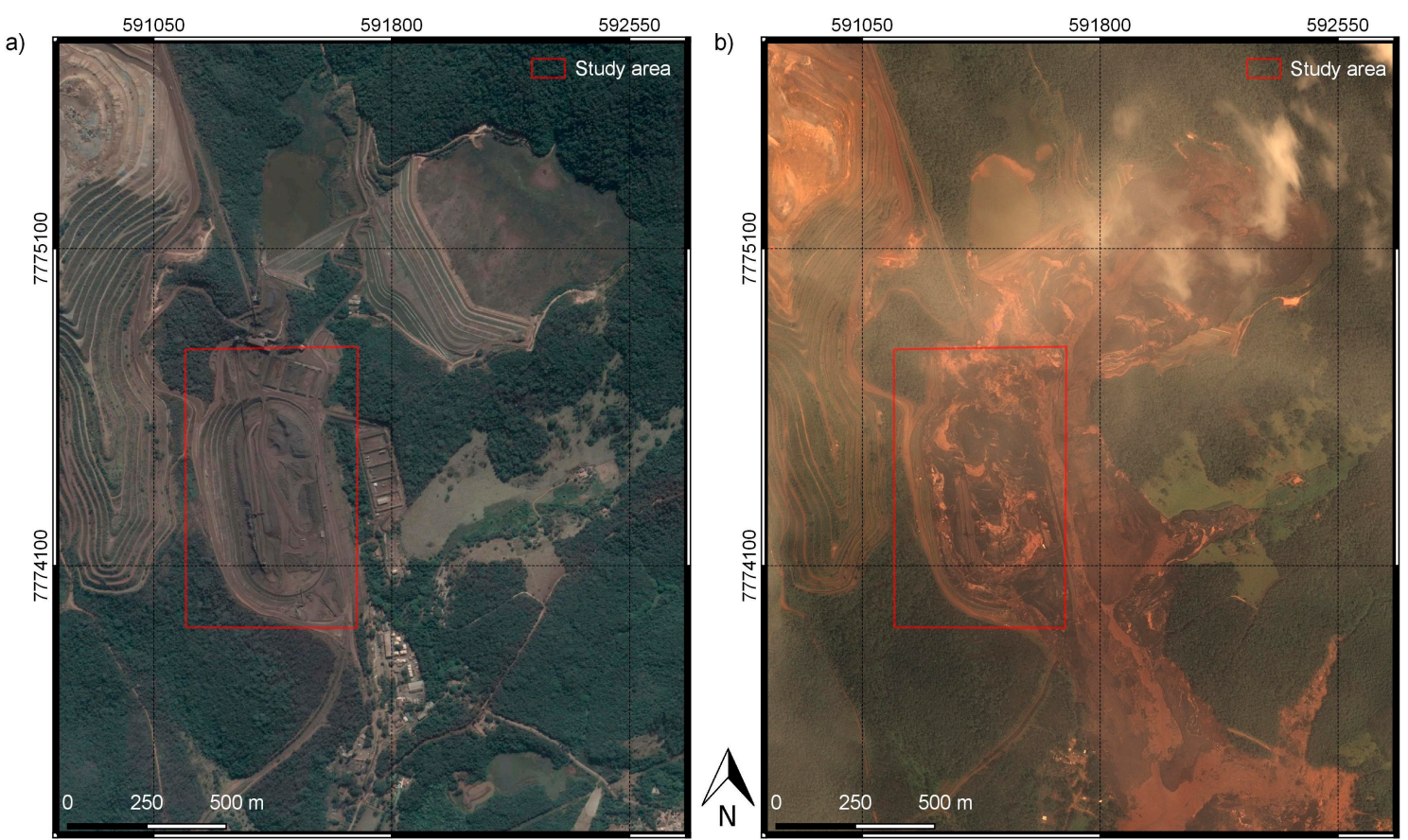

Figure 2. Satellite images show the area of the Córrego do Feijão mine complex in Brumadinho, MG:

(a) before (21 July 2018) and (b) after (27 January 2019) the Brumadinho Dam I collapse.

Volunteer workers from Minas Gerais Military Fire Department have been performing the search and rescue of victims, with support from other Military Fire Departments from the states of São Paulo, Rio de Janeiro, Sergipe, Paraná, Santa Catarina, Rio Grande do Norte, Bahia, and Amazonas, as well as other public services, such as the Military Police of Minas Gerais, the Federal Police, and the National Guard. The rescue work is manual and consists of the removal of mud by excavating machines and the visual location of bodies (or body segments) by firefighters with the help of sniffer dogs. Civilian volunteer services, as the IAG/USP research team, have also been supporting the rescue workers.

Ground-penetrating radar (GPR) is a recommended method for mapping structures, shallow geological features, and subsurface targets, as it is able to locate buried objects under natural (and artificial) disasters [7,8]. GPR is very useful in the exploration of natural resources, the location of underground pipes, and archaeological studies but may also have humanitarian applications.

The idea of applying GPR in Brumadinho occurred shortly after the disaster, aiming to indicate places of interest for excavation which could optimize the rescue operations. However, there was no precedent regarding the efficacy of the method under site conditions characterized by tailings-mud mixture. High-electrical-conductivity soil can cause the attenuation of the electromagnetic wave, reducing or completely preventing the applicability of GPR [9-11].

Despite GPR's limitations under the conditions of mud mixed with iron ore, this work had two major motivations and challenges: (1) to check the applicability of GPR under these specific conditions, and (2) to contribute voluntarily in this humanitarian effort. In this context, the main objective of this pioneering research was to locate structures and objects buried by the tailings-mud mixture of the Brumadinho Dam I. 
The results of this research are presented and discussed in this article. The research could guide excavations to rescue heavy equipment, reducing costs of random excavations and reducing family suffering with the possible location of bodies during the excavations.

\section{GPR Method}

GPR is a nondestructive and noninvasive electromagnetic method that employs radio waves at a very high frequency (typically between $10 \mathrm{MHz}$ and $2.6 \mathrm{GHz}$ ) to locate shallow geological structures, features of the subsurface, or objects buried by man [9]. Detailed information about the theoretical base of the GPR method is presented in the literature, such as [9-11] and others.

The GPR technology is quite versatile and has been consolidated since the 1980s. Currently, geoscientists have applied the GPR method in a range of approaches, such as interference mapping [12-23], natural resources exploration [24-27], environmental contamination studies [28-31], archaeological studies [32-38], forensic studies [39-41], sedimentological studies [42-45], studies of rivers and lakes [46-48], and so forth.

\subsection{GPR Data Acquisition}

The study area is characterized by a dry soil constituted of clay, sand, and friable iron ore, where the pores are filled with air. Therefore, only a few regions of the affected area favored the use of GPR. So, the GPR profiles were acquired in the trails left by the excavating machine, where the leveled terrain allowed the towing of the antennas and equipment.

A total of 53 GPR reflection profiles of 200 and $270 \mathrm{MHz}$ (shielded bistatic antennas) were acquired in the region of Brumadinho, corresponding to $3174 \mathrm{~m}$ of linear extension. All data were acquired with SIR-4000 equipment (GSSI-Geophysical Survey Systems Inc.) in two areas: area 1 (next to the metal structures of Ore Treatment Installation (Instalação de Tratamento de Minério-ITM) and area 2 (next to the train wagons and locomotives). In both areas, GPR profiles were acquired with the common-offset technique in continuous mode, and the interval between traces was $2 \mathrm{~cm}$. In all profiles, the polarization of the electric field Ey was positioned perpendicular to the direction of the profiles to maximize the signal amplitude [15]. Figure 3 indicates the location of the GPR profiles in both study areas. Figure 4 shows photographs of GPR data acquisition using the 200-MHz antenna on the trails left by the excavating machine that compacted and leveled the terrain, which improved significantly the towing of the antennas and the equipment.

Although 53 GPR profiles were acquired in study areas 1 and 2 (Figure 3), this paper presents only the most significant results according to the objectives of this research. For instance, the antenna of $200 \mathrm{MHz}$ (time window $100 \mathrm{~ns}$ ) allowed investigations up to a depth of $3.5 \mathrm{~m}$, and the antenna of $270 \mathrm{MHz}$ (time window $75 \mathrm{~ns}$ ) allowed investigations up to a depth of $2.5 \mathrm{~m}$. Therefore, only the GPR profiles of the 200-MHz antenna are presented. Table 1 shows the start/end of the GPR profiles acquired in areas 1 and 2 (Figure 3), the position of the observed anomalies in each profile, and the result of the excavations.

Table 1. Start/end of the GPR profiles acquired in areas 1 and 2 (Figure 3), the position of the observed anomalies in each profile, and the result of the excavations.

\begin{tabular}{cccc}
\hline & Profile & Start $(\mathbf{m})$ & End $(\mathbf{m})$ \\
\hline Area 1 & Profile 1 & 0 & 120 \\
& \multicolumn{3}{c}{ Anomaly 1, between 26 and 38 m } \\
Area 1 & Obs: The excavation found a concentration of iron ore \\
& Profile 2 & 0 & 123 \\
& \multicolumn{4}{c}{ Anomaly 1, position of 36 m } \\
Area 2 & Obs: The excavation found an accumulation of sand \\
& Profile 1 & 0 & 88 \\
\hline
\end{tabular}


Table 1. Cont.

\begin{tabular}{|c|c|c|c|}
\hline & Profile & Start (m) & End (m) \\
\hline & $\mathrm{O}$ & $\begin{array}{l}\text { (A1), positi } \\
\text { (A2), positi } \\
\text { 3), betwee } \\
\text { nalies were }\end{array}$ & \\
\hline Area 2 & \multicolumn{3}{|c|}{$\begin{array}{l}\text { Anomaly } 1(\mathrm{~A} 1) \text {, between } 48 \text { and } 54 \mathrm{~m} \\
\text { Anomaly } 2 \text { (A2), between } 77.3 \text { and } 79 \mathrm{~m} \\
\text { Obs: The anomalies were not excavated }\end{array}$} \\
\hline
\end{tabular}

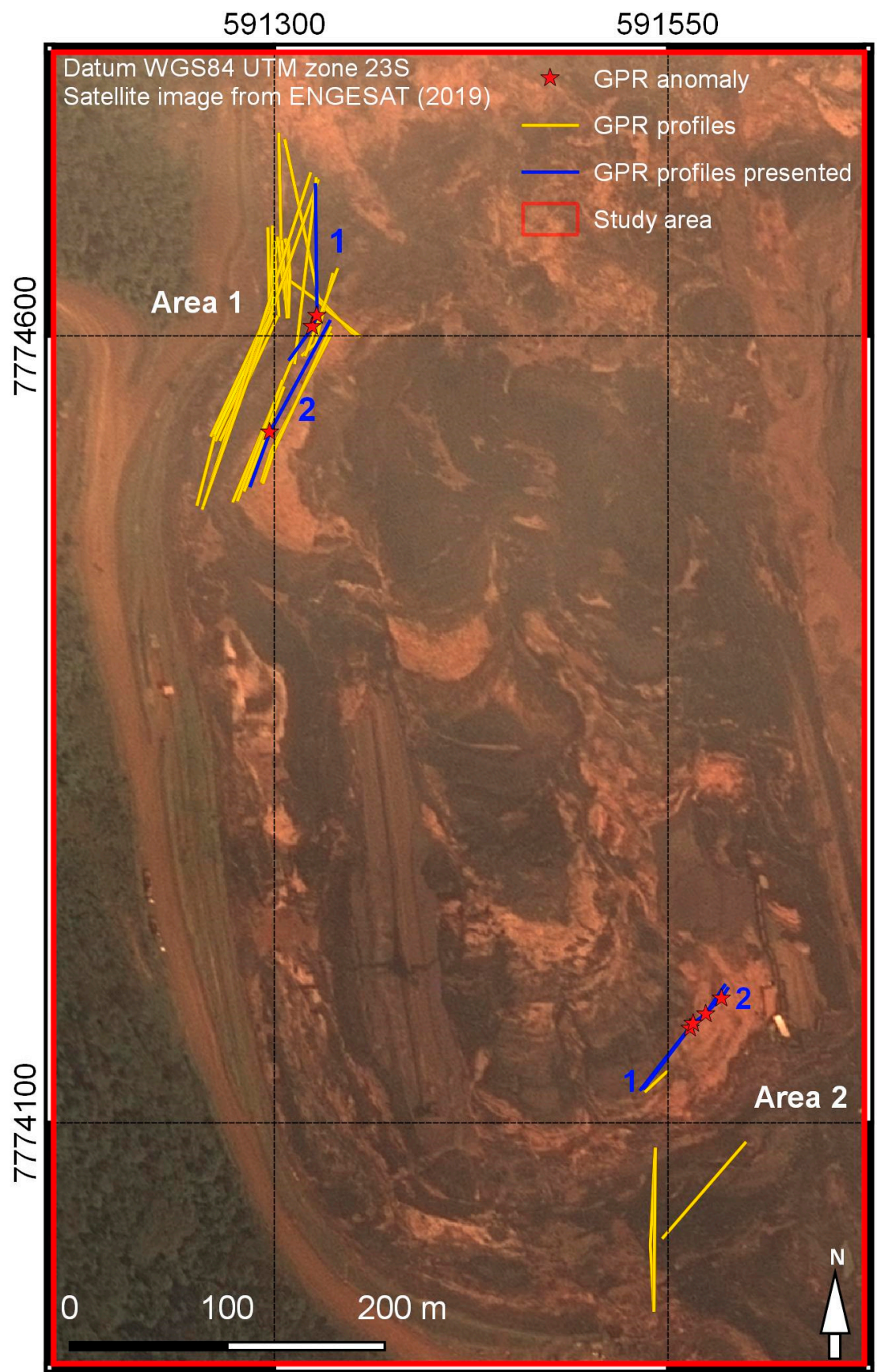

Figure 3. Location of ground-penetrating radar (GPR) profiles in the two study areas in the Brumadinho mine. Area 1, near the Ore Treatment Installation (Instalação de Tratamento de Minério-ITM). Area 2, near the train wagons and a locomotive. 

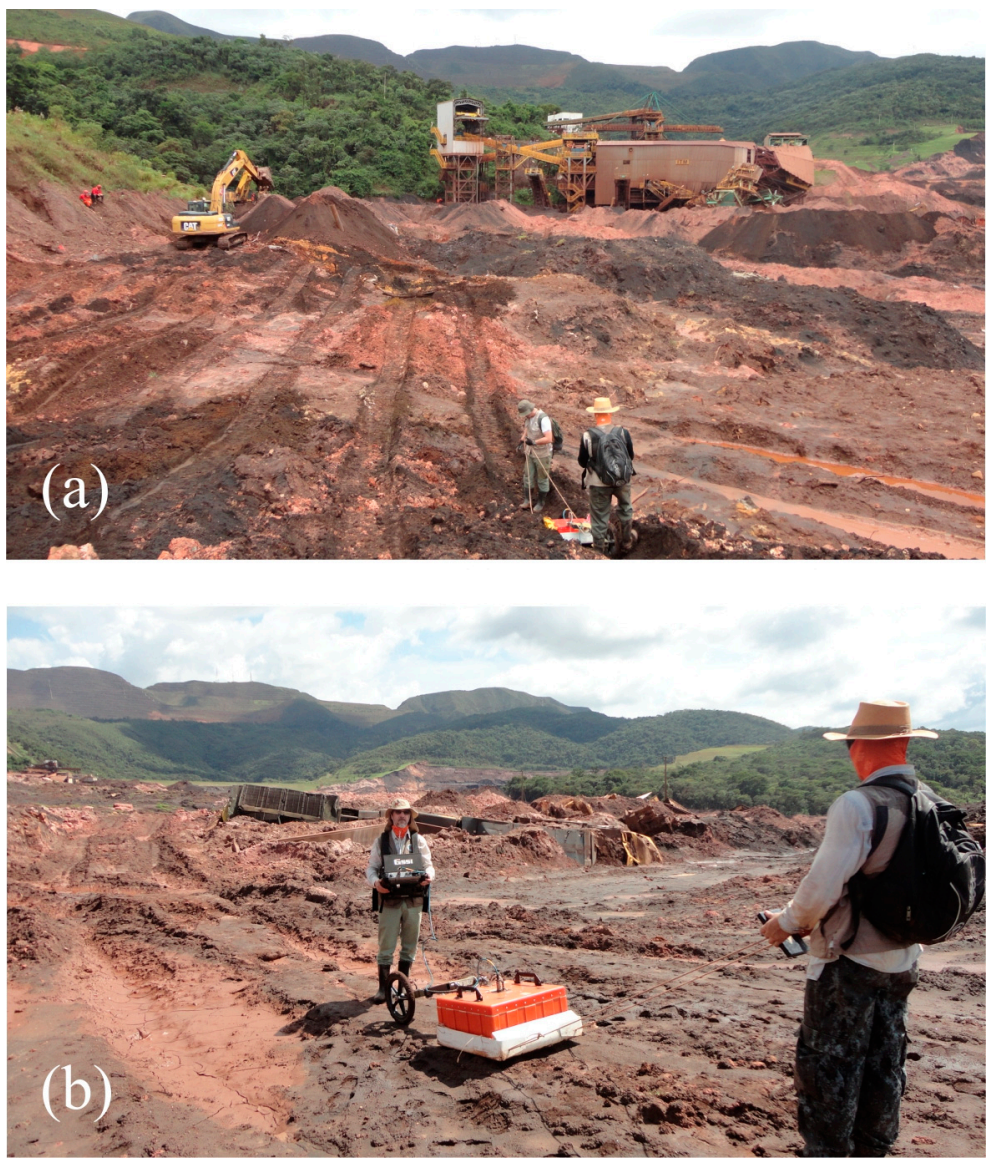

Figure 4. Acquisition of GPR profiles with SIR-4000 equipment and 200-MHz shielded antennas (GSSI) on the tracks left by the excavating machine in area 1 (a) and area 2 (b).

\subsection{GPR Data Processing}

The GPR data were processed using RADAN 7.0 (GSSI) to improve the visualization of the objects and structures buried in the tailings-mud mixture. The main steps used in the processing routine were: time-zero correction, band-pass filtering, time-varying linear gain, moving average filter, background removal filter, and time-depth conversion.

Band-pass filtering on the time domain (55-275 MHz) reduced the low- and high-frequency noise amplitude and improved the signal-to-noise ratio.

The time-varying linear gains were applied to compensate for energy losses due to absorption, spherical divergence, and signal scattering, thus preserving the signal amplitude hierarchy. The moving average filter of three traces resulted in horizontal smoothing, while the background removal filter eliminated the horizontal reflectors and improved visualization of diffraction hyperbolas from discrete objects buried in the subsurface.

Time-depth conversion was performed by using an electromagnetic wave velocity value of $0.083 \mathrm{~m} / \mathrm{ns}$ (dielectric constant of 13). For area 1, the velocity was obtained by the expression $\mathrm{v}=2 \mathrm{~h} / \mathrm{t}$, where (h) is the depth of a known target (metal pipe) buried at $0.45 \mathrm{~m}$ depth and $(\mathrm{t})$ is the transit time (two-way travel time) of the electromagnetic wave in the subsurface obtained through the GPR profile. For area 2, the velocity was obtained by using Dix's formula [49] from data obtained by analyzing the geometry of hyperbola $\mathrm{H} 2$ associated with the reflection of anomaly A2 observed in position $22.3 \mathrm{~m}$ at $0.9 \mathrm{~m}$ depth from profile 1 (Table 1). Figure 5 shows the placement of a metal pipe and the acquisition of its GPR profile in order to calculate the propagation velocity of the electromagnetic wave in the subsurface. In the next section, the GPR profiles are presented and discussed in depth. 

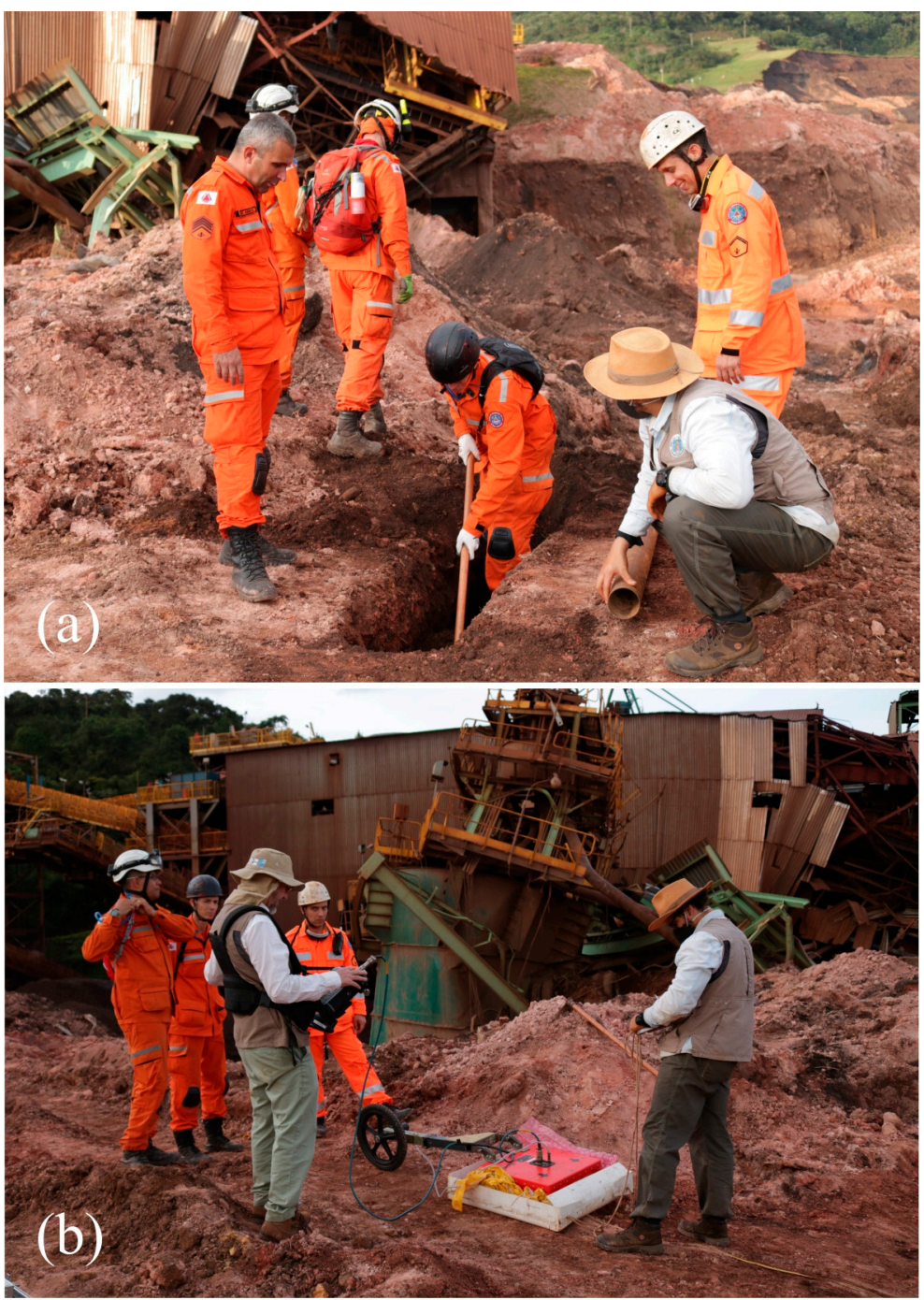

Figure 5. (a) Excavation of a trench for the placement of a metal pipe at a known depth. (b) GPR profile acquisition on the metal pipe installed in (a) to calculate the propagation velocity of the GPR electromagnetic wave.

\section{Results}

\subsection{GPR Profiles in Area 1}

Figure 6 shows a segment of the GPR 1 profile, acquired with the 200-MHz antenna, located near ITM in area 1 (Figure 3) and photography of the excavation detecting iron ore. The 200-MHz antenna showed a good capacity of penetration on the subsurface, achieving $3.5 \mathrm{~m}$ depth. This profile showed anomalous high-amplitude reflections between 26 and $38 \mathrm{~m}$, from 0.5 down to $2.5 \mathrm{~m}$ (see black dashed rectangle in the figure) compared with the strongly attenuated signal from the rest of the radargram. This anomalous region was excavated, which allowed it to be related to an ITM iron ore accumulation that was dragged by the mud and deposited in this segment of the profile. 


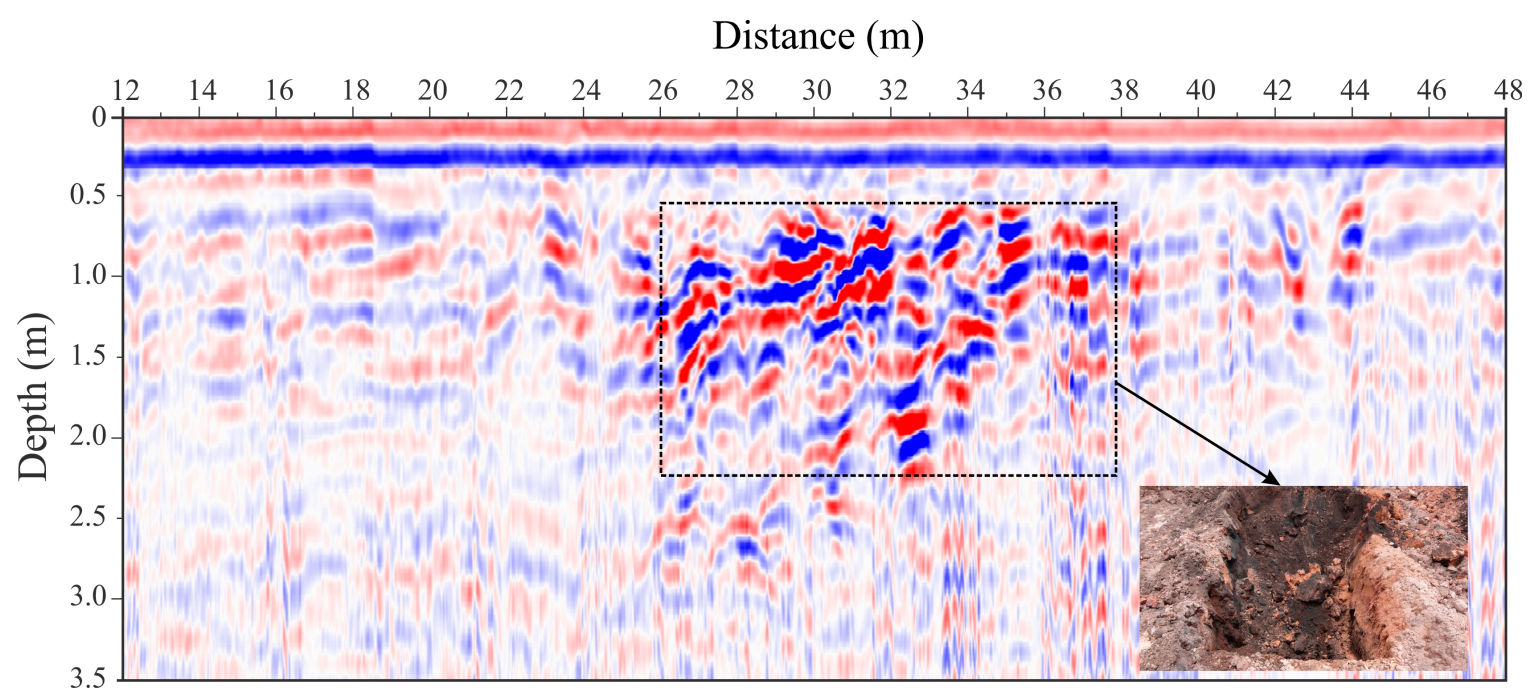

Figure 6. Segment of the GPR 1 profile of $200 \mathrm{MHz}$ acquired in area 1. The black dashed rectangle highlights the anomalous region, and the photograph shows the friable iron ore found after the excavation.

Figure 7 shows a segment of the GPR 2 profile, acquired with the $200-\mathrm{MHz}$ antenna, located near ITM in area 1 (Figure 3). This profile showed a clear anomalous reflection between 34 and $38 \mathrm{~m}$, from 0.8 down to $2 \mathrm{~m}$ depth. It is highlighted with a black dashed rectangle in the figure. Note the strongly attenuated signal for the rest of the radargram. This anomalous region was also excavated, which allowed it to be related to a sand accumulation coming from the dam's filter that was probably dragged by the mud and deposited in this segment of the profile.

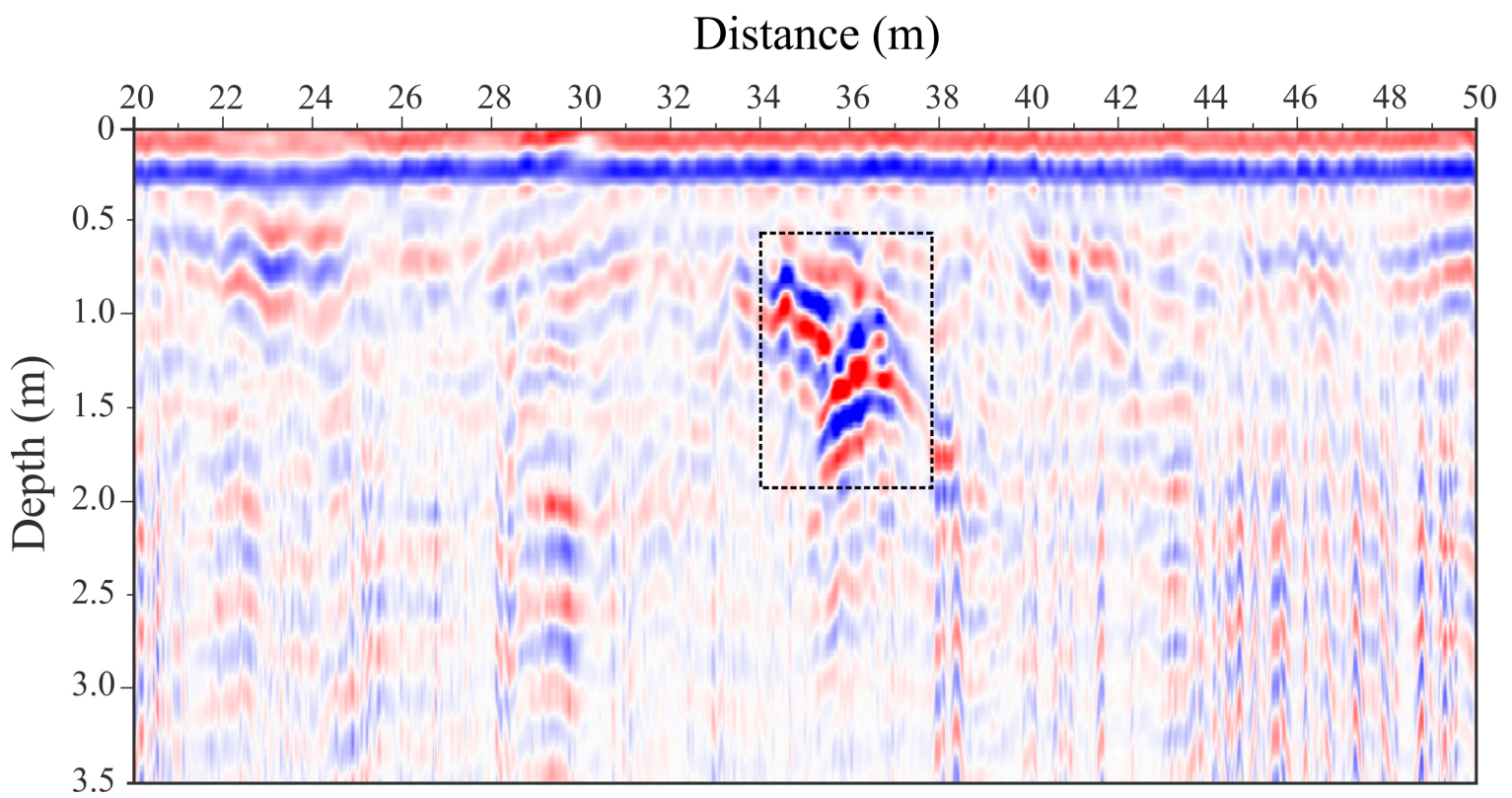

Figure 7. Segment of the GPR 2 profile of $200 \mathrm{MHz}$ acquired in area 1. The black dashed rectangle highlights the anomalous region.

\subsection{GPR Profiles in Area 2}

Figure 8 shows a segment of the GPR 1 profile, acquired with the 200-MHz antenna, located near the train wagons in area 2 (Figure 3). This profile showed three anomalous reflections (A1, A2, and A3), clearly identified in the figure. On the rest of the radargram, the signal was strongly attenuated. 
The first two anomalies were characterized by clear hyperbolic reflections associated with punctual targets and the third anomaly was characterized by plane-parallel reflections. All reflections presented high amplitude and excavations were recommended.

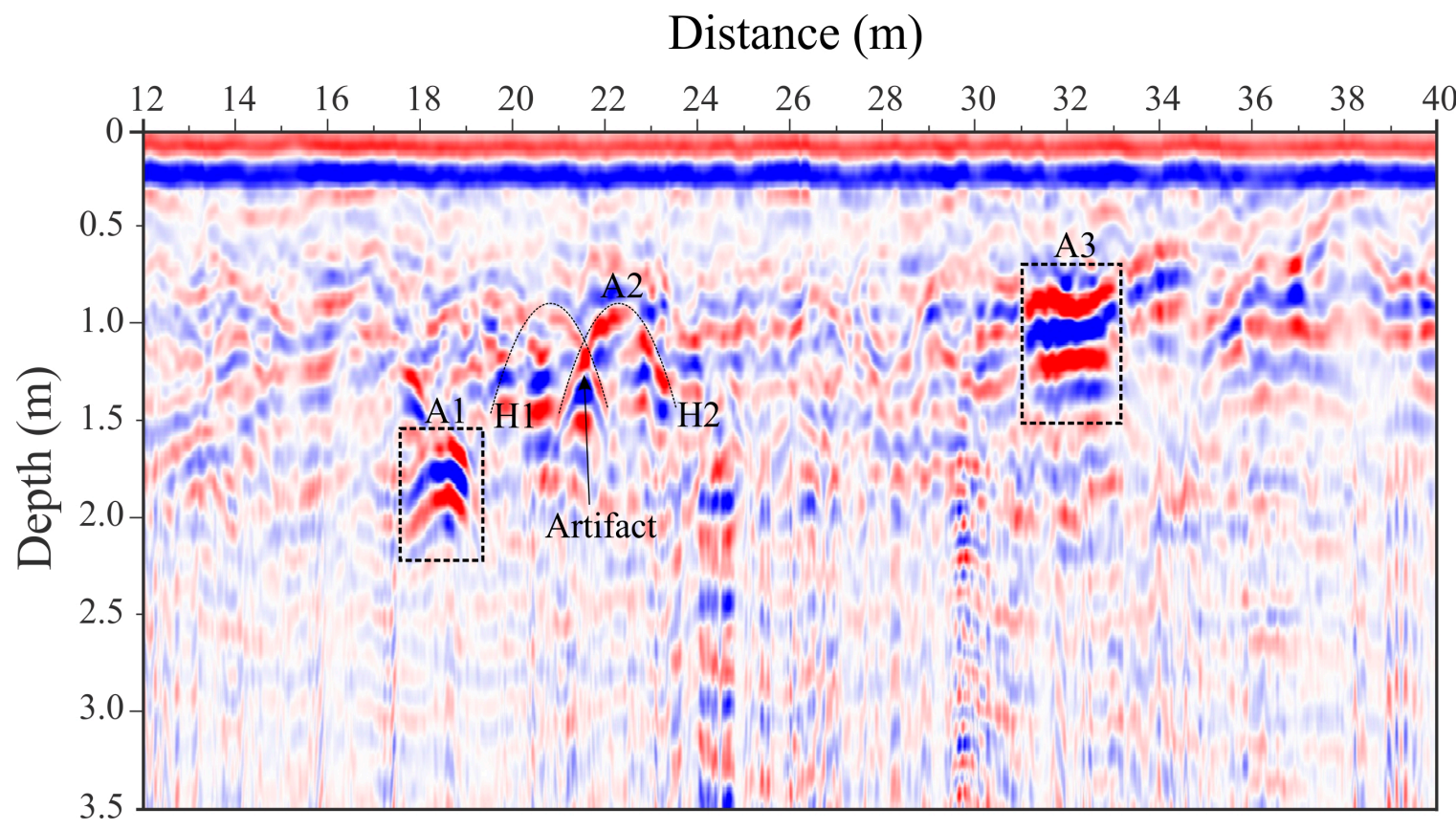

Figure 8. Segment of the GPR 1 profile of $200 \mathrm{MHz}$ acquired in area 2. The black dashed rectangles highlight anomalies A1 and A3. Anomaly A2 is represented by hyperbole H2.

Figure 9 shows a segment of the GPR 2 profile acquired with the 200-MHz antenna, located near the train wagons in area 2 (Figure 3). In this profile, two anomalous regions (A1 and A2) are highlighted by black dashed rectangle in the figure. All reflections presented high amplitude and excavations were highly recommended.

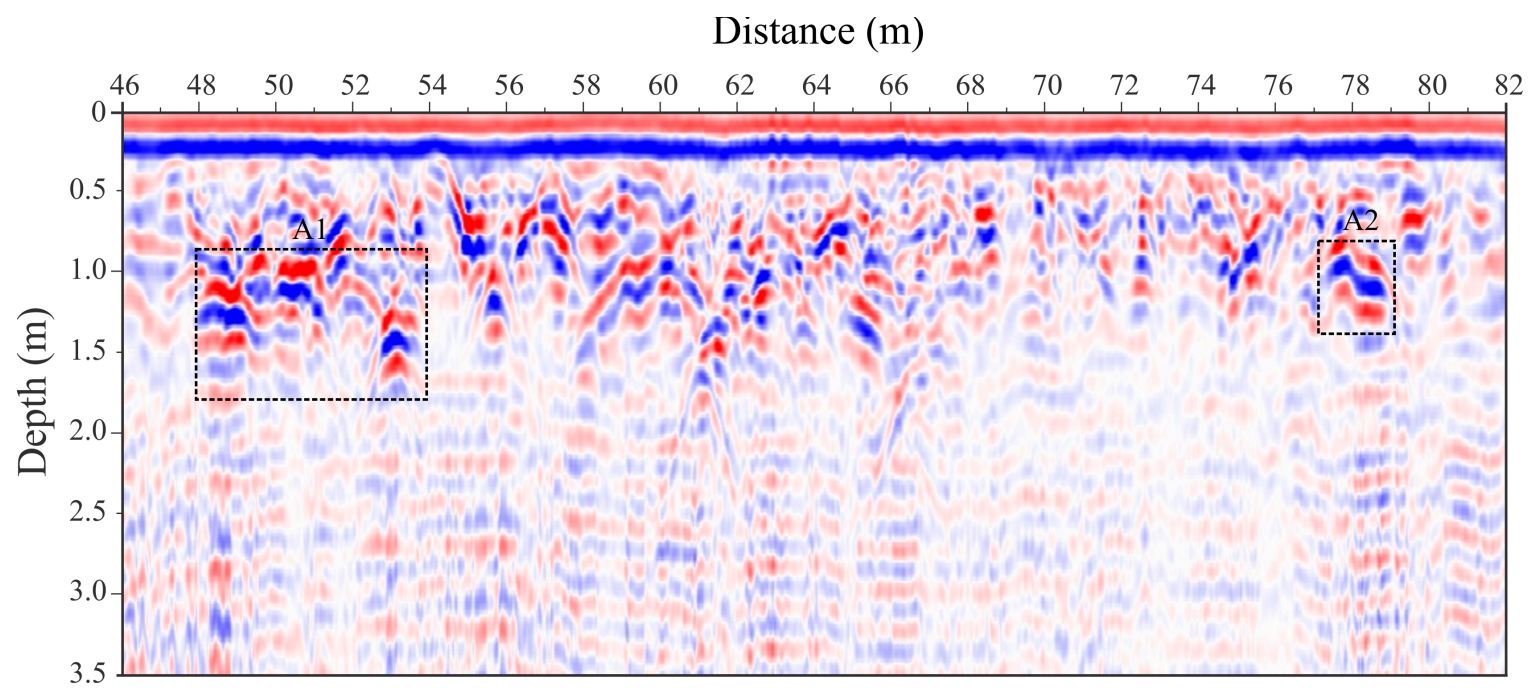

Figure 9. Segment of the GPR 2 profile of $200 \mathrm{MHz}$ acquired in area 2. The black dashed rectangles highlight anomalies A1 and A2. 


\section{Discussion}

All the GPR profiles acquired for areas 1 and 2 of Dam I in Brumadinho had low attenuation due to the dry soil. During the fieldwork and excavations, it was observed that the soil was constituted of clay, sand, and friable iron ore, where the pores were filled with air. This fact likely resulted in the good penetration and reflection of the GPR up to $3.5 \mathrm{~m}$ depth for the 200-MHz antenna.

In Figure 8, three hyperbolic reflectors are observed. The top of hyperbole H1 is not very clear, but the top of hyperbole $\mathrm{H} 2$ is very clear. The vertex of hyperbole $\mathrm{H} 2$ corresponds to anomaly A2. Note that a third hyperbolic reflector appears in position $21.5 \mathrm{~m}$ and $1.25 \mathrm{~m}$ depth, between $\mathrm{H} 1$ and $\mathrm{H} 2$. This is the artifact caused by electromagnetic wave reflections from target $1(\mathrm{H} 1)$ to target $2(\mathrm{H} 2)$ before it returned to the surface. This result is similar to the one discussed in the article by Porsani and Sauck [14], in which they proved the artifact origin and presented an effective procedure for removal of hyperbolic artifacts caused by multiple targets in the subsurface.

Despite the promising results, there is a lack of GPR publications aiming to locate buried objects after natural and artificial disasters. For instance, in article [7], GPR was used in a cemetery in Indonesia to simulate to detection of bodies buried from two weeks to two years before the surveys. The results showed a greater contrast in the reflection amplitude in the more recently buried bodies, whereas the amplitude for bodies buried more than one year prior to the study showed a weaker contrast. The authors proposed the use of the GPR method in order to increase the effectiveness and efficiency in the search for disaster victims.

In another example [8], the author applied GPR to detect landmines in Afghanistan in support of humanitarian aid. According to the author, the soil in landmine fields is very inhomogeneous, as it contains much gravel and many tree roots. As a result, it became almost impossible, under real conditions, to detect mines buried in the soil of the studied minefield. The author recommended applying the migration step to the GPR data to improve the images of the subsoil.

In the studies carried out in Brumadinho, GPR anomalies were located in real time during data acquisition and excavated with a power shovel when possible. This procedure was used in the fieldwork due to the urgency required for searches of bodies, as required in disaster areas.

As discussed above, the main similarity between this study and articles [7] and [8] is that the GPR method can be used for humanitarian purposes by optimizing searches and detecting areas of interest for excavations.

\section{Conclusions}

The GPR results were surprising and allowed the detection of areas of interest in the subsoil, such as iron ore concentration and sand accumulation from the dam filter. The positive results proved that GPR was able to penetrate under conditions of mud mixed with friable iron ore, contradicting low expectations of GPR success.

Although no bodies or underground equipment were found, the results served to eliminate the studied areas from future excavations, thus redirecting and optimizing the rescue operations. These important results can serve as an additional motivation for the use of GPR in future humanitarian work in disaster areas.

The GPR studies showed that it is important to survey before digging. This procedure can orientate the search and rescue, reduce costs from random excavations, and increase the chances of finding bodies.

Author Contributions: J.P., F.J., and M.S. performed the data acquisition; J.P. and F.J. analyzed the data; J.P. and F.J. wrote the paper; J.P., F.J., and M.S. revised the paper.

Funding: This research received no external funding.

Acknowledgments: To Pedro Leite da Silva Dias, Director of IAG/USP, and Renato Luiz Prado, Head of the Department of Geophysics at IAG/USP, for supporting our initiatives and providing infrastructure support. JP acknowledges CNPq-Conselho Nacional de Desenvolvimento Científico e Tecnológico, the Brazilian Research Agency, for providing research support (303731/2017-6). To Max Mena, Eduardo, Maria Cecilia, and colleagues 
from the São Paulo Military Fire Department for supporting our initiatives. To Edgard Estevo da Silva, Almeida, William, Cosendey, Marcia, Vicente, Rocha, Helder, and colleagues from the Minas Gerais Military Fire Department for providing infrastructure support. To aspirants from the Minas Gerais Military Fire Department Henrique (Da Silva), Queiroz, Rojer e Jocélio for helping during the field works for data acquisition. We also thank Luciana Hiromi Yamada da Silveira, journalist of IAG/USP, for his corrections to the English text. Finally, we thank the anonymous reviewers for their valuable critiques and suggestions which improved the article.

Conflicts of Interest: The authors declare no conflict of interest.

\section{References}

1. Cavallini, M. Mina Que Abriga Barragem em Brumadinho Responde por 2\% da Produção da Vale; Veja Raio-X. Available online: https://g1.globo.com/economia/noticia/2019/01/28/mina-queabriga-barragem-em-brumadinho-responde-por-2-da-producao-da-vale-veja-raio-x.ghtml (accessed on 28 January 2019).

2. Figueiredo, M.A.; Varajão, A.F.D.C.; Fabris, J.D.; Loutfi, I.S.; Carvalho, A.P. Alteração superficial e pedogeomorfologia no sul do Complexo Bação-Quadrilátero Ferrífero (MG). Rev. Bras. Ciênc. Solo (Online) 2004, 28, 713-729. [CrossRef]

3. Bizzi, L.A.; Schobbenhaus, C.; Gonçalves, J.H.; Baars, F.J.; Delgado, I.M.; Abram, M.B.; Leão Neto, R.; Matos, G.M.M.; Santos, J.O.S. Geologia, tectônica e recursos minerais do Brasil: Sistema de informações geográficas. Escala 1:2.500.000. Brasília [CD-ROM] 2001, CPRM, 4.

4. Nitahara, A. Vale-Anuncia-Plano-Para-Novo-Padrao-de-Seguranca-Nas-Barragens. Available online: http:/ / agenciabrasil.ebc.com.br/geral/noticia/2019-01/vale-anuncia-plano-para-novo-padrao-deseguranca-nas-barragens (accessed on 1 March 2019).

5. Jornal o Diário. Available online: http:/ / www.jornalodiario.com.br/imprime.php?cid=179453\&sid=550 (accessed on 4 March 2019).

6. G1 Minas-Belo Horizonte. Available online: https://g1.globo.com/mg/minas-gerais/noticia/2019/ 03/25/sobe-para-214-o-numero-de-mortos-identificados-na-tragedia-de-brumadinho.ghtml (accessed on 27 March 2019).

7. Dewi, R.K.; Kurniawan, A.; Taqwantara, R.F.; Iskandar, F.M.; Naufal, T.Z.; Widodo. Identification of buried victims in natural disaster with GPR method. AIP Conf. Proc. 2017, 1861, 30022.

8. Sato, M. Near range radar and its application to near surface geophysics and disaster mitigation. J. Earth Sci. 2015, 26, 858-863. [CrossRef]

9. Porsani, J.L. Ground Penetrating Radar (GPR): Proposta Metodológica de Emprego em Estudos Geológico-Geotécnicos Nas Regiões de Rio Claro e Descalvado-SP. Ph.D. Thesis, Instituto de Geociências e Ciências Exatas, UNESP, Campus de Rio Claro-SP, Brazil, 1999.

10. Daniels, D.J. Ground Penetrating Radar. IET Radar, Sonar, Navigation and Avionics Series 15, 2nd ed.; Institution of Engineering and Technology: London, UK, 2007; p. 726.

11. Jol, H.M. Ground Penetrating Radar: Theory and Applications, 1st ed.; Elsevier: Amsterdam, The Netherlands, 2009; 509p.

12. Zeng, X.; McMechan, G.A. GPR characterization of buried tanks and pipes. Geophysics 1997, 62, 797-806. [CrossRef]

13. Grandjean, G.; Gourry, J.C.; Bitri, A. Evaluation of GPR techniques for civil-engineering applications: Study on a test site. J. Appl. Geophys. 2000, 45, 141-156. [CrossRef]

14. Porsani, J.L.; Sauck, W.A. Ground-penetrating radar profiles over multiple steel tanks: Artifact removal through effective data processing. Geophysics 2007, 72, J77-J83. [CrossRef]

15. Porsani, J.L.; Slob, E.; Lima, R.S.; Leite, D.N. Comparing detection and location performance of perpendicular and parallel broadside GPR antenna orientations. J. Appl. Geophys. 2010, 70, 1-8. [CrossRef]

16. Porsani, J.L.; Ruy, Y.B.; Ramos, F.P.; Yamanouth, G.R.B. GPR applied to mapping utilities along the route of the Line 4 (yellow) subway tunnel construction in São Paulo City, Brazil. J. Appl. Geophys. 2012, 80, 25-31. [CrossRef]

17. Santos, V.R.N.; Al-Nuaimy, W.; Porsani, J.L.; Hirata, N.S.T.; Alzubi, H.S. Spectral analysis of ground penetrating radar signals in concrete, metallic and plastic targets. J. Appl. Geophys. 2014, 100, $32-43$. [CrossRef] 
18. Metwaly, M. Application of GPR technique for subsurface utility mapping: A case study from urban area of Holy Meca, Saudi Arabia. Measurement 2015, 60, 139-145. [CrossRef]

19. Porsani, J.L.; Almeida, E.R.; Poluha, B.; Santos, V.R.N. GPR tomographic imaging of concrete tubes and steel/plastic tanks buried in IAG/USP geophysical test site, Brazil. Int. J. Geosci. 2017, 8, 647-658. [CrossRef]

20. Porsani, J.L.; Poluha, B.; Santos, V.R.N. GPR profiles over plastic drums buried at the IAG/USP geophysical test site-I, São Paulo, Brazil: A controlled experiment applied to environmental studies. First Break 2018, 36, 65-70.

21. Ukaegbu, I.K.; Gamage, K.A.A.; Aspinall, M.D. Nonintrusive depth estimation of buried radioactive wastes using ground penetrating radar and a gamma ray detector. Remote Sens. 2019, 11, 141. [CrossRef]

22. Naval, V.S.; Santos-Assunção, S.; Pérez-Gracia, V. GPR clutter amplitude processing to detect shallow geological targets. Remote Sens. 2018, 10, 88. [CrossRef]

23. Volkomirskaya, L.B.; Gulevich, O.A.; Varenkov, V.V.; Sakhterov, V.I. Requirements for the performance of a ground-penetrating radar system in searching for cavities. Russian Geol. Geophys. 2018, 59, 438-447. [CrossRef]

24. Porsani, J.L.; Elis, V.R.; Hiodo, F.Y. Geophysical investigations for the characterization of fractured rock aquifers in Itu, SE Brazil. J. Appl. Geophys. 2005, 57, 119-128. [CrossRef]

25. Porsani, J.L.; Sauck, W.A.; Souza, A.O., Jr. GPR for mapping fractures and as a guide for the extraction of ornamental granite from a quarry: A case study from southern Brazil. J. Appl. Geophys. 2006, 58, 177-187. [CrossRef]

26. Martínez, J.; Montiel, V.; Rey, J.; Cañadas, F.; Vera, P. Utilization of integrated geophysical techniques to delineate the extraction of mining bench of ornamental rocks (marble). Remote Sens. 2017, 9, 1322. [CrossRef]

27. Francke, J.; Utsi, V. Advances in long-range GPR systems and their applications to mineral exploration, geotechnical and static correction problems. First Break 2009, 27, 7.

28. Porsani, J.L.; Malagutti Filho, W.; Elis, V.R.; Dourado, J.C.; Moura, H.P. The Use of GPR and VES in delineating a contamination plume in a landfill site: A case study in SE Brazil. J. Appl. Geophys. 2004, 55, 199-209. [CrossRef]

29. Bertolla, L.; Porsani, J.L.; Soldovieri, F.; Catapano, I. GPR-4D monitoring a controlled LNAPL spill in a masonry tank at USP, Brazil. J. Appl. Geophys. 2014, 103, 237-244. [CrossRef]

30. Andersen, T.R.; Poulsen, S.E.; Thomsen, P.; Havas, K. Geological characterization in urban areas based on geophysical mapping: A case study from Horsens, Denmark. J. Appl. Geophys. 2018, 150, 338-349. [CrossRef]

31. Steelman, C.M.; Klazingab, D.R.; Cahilla, A.G.; Endresb, A.L.; Parker, B.L. Monitoring the evolution and migration of a methane gas plume in an unconfined sandy aquifer using time-lapse GPR and ERT. J. Contam. Hydrol. 2017, 205, 12-24. [CrossRef]

32. Rodrigues, S.I.; Porsani, J.L.; Santos, V.R.N.; De Blasis, P.A.D.; Giannini, P.C.F. GPR and inductive electromagnetic surveys applied in three coastal sambaqui (shell mounds) archaeological sites in Santa Catarina state, south Brazil. J. Archaeol. Sci. 2009, 36, 2081-2088. [CrossRef]

33. Porsani, J.L.; Jangelme, G.M.; Kipnis, R. GPR survey at Lapa do Santo archaeological site, Lagoa Santa karstic region, Minas Gerais state, Brazil. J. Archaeol. Sci. 2010, 37, 1141-1148. [CrossRef]

34. Porsani, J.L.; Kipnis, R.; Santos, V.R.N.; Almeida, E.R.; Fernandes, I. GPR tomography as support for an archaeological excavation in Aripuanã indigenous cemetery, Amazon region, Brazil. Int. J. Geosci. 2017, 8, 1264-1277. [CrossRef]

35. Masini, N.; Capozzoli, L.; Chen, P.; Chen, F.; Romano, G.; Lu, P.; Tang, P.; Sileo, M.; Ge, Q.; Lasaponara, R. Towards an operational use of geophysics for archaeology in Henan (China): Methodological approach and results in Kaifeng. Remote Sens. 2017, 9, 809. [CrossRef]

36. Panisova, J.; Murín, I.; Pašteka, R.; Haličková, J.; Brunčák, P.; Pohánka, V.; Papčo, J.; Milo, P. Geophysical fingerprints of shallow cultural structures from microgravity and GPR measurements in the Church of St. George, Svätý Jur, Slovakia. J. Appl. Geophys. 2016, 127, 102-111. [CrossRef]

37. Martínez, J.; Rey, J.; Gutiérrez, L.M.; Novo, A.; Ortiz, A.J.; Alejo, M.; Galdón, J.M. Electrical resistivity imaging (ERI) and ground-penetrating radar (GPR) survey at the Giribaile site (upper Guadalquivir valley; southern Spain). J. Appl. Geophys. 2015, 123, 218-226. [CrossRef]

38. Urban, T.M.; Leon, J.F.; Manning, S.W.; Fisher, K.D. High resolution GPR mapping of late bronze age architecture at Kalavasos-Ayios Dhimitrios, Cyprus. J. Appl. Geophys. 2014, 107, 129-136. [CrossRef] 
39. Almeida, E.R.; Porsani, J.L.; Catapano, I.; Gennarelli, G.; Soldovieri, F. Microwave tomography-enhanced GPR in forensic surveys: The case study of a tropical environment. IEEE J. Sel. Top. Appl. Earth Observ. Remote Sens. 2016, 9, 115-124. [CrossRef]

40. Cavalcanti, M.M.; Rocha, M.P.; Blum, M.L.B.; Borges, W.R. The forensic geophysical controlled research site of the University of Brasilia, Brazil: Results from methods GPR and electrical resistivity tomography. Forensic Sci. Int. 2018, 293, e101.e1-e101.e21. [CrossRef]

41. Molina, C.M.; Pringle, J.K.; Saumett, M.; Evans, G.T. Geophysical monitoring of simulated graves with resistivity, magnetic susceptibility, conductivity and GPR in Colombia, South America. Forensic Sci. Int. 2016, 261, 106-115. [CrossRef]

42. Oliveira, M.A.T.; Porsani, J.L.; Lima, G.L.; Jeske-Pieruschka, V.; Behling, H. Upper pleistocene to holocene peatland evolution in southern Brazilian highlands as depicted by radar stratigraphy, sedimentology and palynology. Quat. Res. 2012, 77, 397-407. [CrossRef]

43. Rodrigues, S.I.; Porsani, J.L.; Giannini, P.C.F.; Fornari, M.; Atorre, T.; De Blasis, P.A.D.; Ruiz, D.M.G. Radar facies and sedimentological analysis: Study of sedimentary substrate from an archaeological site (shell mound), southern of Brazil. Holocene 2015, 1, 1-14.

44. Forte, E.; Pipan, M.; Casabianca, D.; Di Cuia, R.; Riva, A. Imaging and characterization of a carbonate hydrocarbon reservoir analogue using GPR attributes. J. Appl. Geophys. 2012, 81, 76-87. [CrossRef]

45. Tatum, D.I.; Francke, J. Constructing hydrocarbon reservoir analogues of aeolian systems using ground penetrating radar. J. Appl. Geophys. 2012, 81, 21-28. [CrossRef]

46. Porsani, J.L.; Assine, M.L.; Moutinho, L. Application of GPR in the study of a modern alluvial megafan: The case of the Taquari River in Pantanal wetland, west-central Brazil. Subs. Sens. Tech. Appl. 2005, 6, 219-233. [CrossRef]

47. Leandro, C.G.; Barboza, E.G.; Caron, F.; Jesus, F.A.N. GPR trace analysis for coastal depositional environments of southern Brazil. J. Appl. Geophys. 2019, 162, 1-12. [CrossRef]

48. Rocha, T.B.; Fernandez, G.B.; Rodrigues, A. Registros de erosão e progradação revelados por radar de penetração do solo (GPR) na barreira regressiva pleistocênica do complexo deltaico do Rio Paraíba do Sul (RJ). Quat. Environ. Geosci. 2017, 8, 24-37. [CrossRef]

49. Dix, C.H. Seismic velocities from surface measurements. Geophysics 1955, 20, 68-86. [CrossRef] 